\title{
О мнимой и реальной экономической эффективности борьбы с лесными пожарами в Сибири ${ }^{1}$
}

Б.Н. ПОРФИРЬЕВ, академИк РАН, Институт народнохозяйственного прогнозирования РАН, Москва. E-mail: b_porfiriev@mail.ru

Аннотация. Дана критическая оценка существующего подхода к экономической оценке последствий лесных пожаров, в результате которого сильно недооцениваются риски и ущерб для здоровья и жизни людей. Применение этого подхода при организации тушения лесных пожаров в Сибири летом 2019 г. привело к отказу от тушения огня на большой территории так называемых зон контроля. Исходя из (а) приоритетов угроз для здоровья и жизни населения (из них главную опасность представляет не огонь, а содержащий вредные и токсичные вещества дым), (б) принятых ВОЗ критериев эффективности мер спасения жизни, автор доказывает, что затраты на тушение лесных пожаров являются эффективными с социально-экономической точки зрения; а затраты, связанные с локализацией очагов лесных пожаров на доступных участках зон контроля - высокоэффективными. Обосновано, что проблема лесных пожаров по своей значимости относится к категории задач обеспечения национальной безопасности, и ее решение требует комплексного подхода, отрицающего используемый до сих пор сугубо фискальный способ оценки эффективности затрат на меры пожаротушения.

Ключевые слова: лесные пожары; зоны контроля; меры тушения пожаров; затраты; риск; жизнь и здоровье людей; социально-экономическая эффективность; природные риски; государственное управление

Особенностью северного лета 2019 г. стали масштабные пожары, охватившие большие пространства Восточной Сибири, Аляски и Гренландии. Многие специалисты считают эти пожары беспрецедентными даже с учетом тенденции последних десятилетий, в течение которых площадь бореальных лесов мира, пройденная огнем, превзошла уровень, считавшийся нормальным в течение минувших 10 тыс. лет. Максимальной силы пожары достигли в июне и июле, когда температура воздуха превышала средние значения за период 1981-2010 гг. на 8-10 $\mathrm{C}$ и горючесть лесов резко повысилась. По оценкам Европейского центра

${ }^{1}$ Статья подготовлена в рамках Программы ФНИ ГАН на 2013-2020 годы (темы $\left.168 \_3,167\right)$, а также Программы Президиума РАН № 10. Статья развивает, дополняет и обновляет более раннюю публикацию автора. См: [Порфирьев, 2019]. 
среднесрочного прогноза погоды, мощность теплового излучения от лесных пожаров на арктических территориях в отдельные дни этих летних месяцев 2019 г. достигала 27 ГВт, а среднесуточные значения более чем вчетверо превысили аналогичный показатель за предшествующие пять лет [Ice and fire, 2019] (рис. 1).

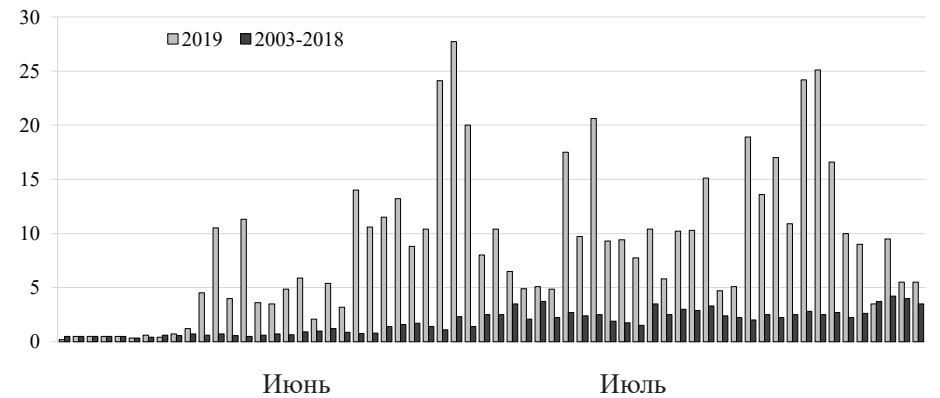

Puc. 1. Мощность теплового излучения от лесных пожаров на арктических территориях в 2003-2018 гг., 2019 г. (июнь-июль), ГВт

По данным ФБУ «Авиалесоохрана» на 09.08.2019, в России сгорело более 2,5 млн га лесов, тушение продолжалось на территории около 198 тыс. га [Непомнящая, 2019]. По оценке Рослесхоза, на указанную дату площадь лесных пожаров достигала 4 млн га [Если пожар.., 2019].

Наибольшего масштаба и силы лесные пожары достигли в Сибири, прежде всего в Якутии, Красноярском крае и Иркутской области. На конец июля 2019 г. лесные пожары охватили более 3,3 млн га макрорегиона. Дым от них, накрыв сотни населенных пунктов в Сибири, достиг Поволжья, Казахстана, Монголии и даже Аляски.

\section{Социально-экономические последствия пожаров}

Сложившаяся чрезвычайная ситуация обусловлена комплексом причин, среди которых не последнее место занимает аномально жаркое лето, рассматриваемое как проявление глобального потепления. Однако большинство специалистов обращают внимание на тот факт, что борьба с пожарами велась только на 3,3\% площади охваченных огнем лесов, в то время как на остальной территории - в так называемых зонах контроля 
лесных пожаров ${ }^{2}$ - огонь не тушили. Такие решения были приняты комиссиями субъектов Федерации по предупреждению и ликвидации чрезвычайных ситуаций и обеспечению пожарной безопасности (КЧС). Последние при этом опирались на приказ Минприроды России № 426 от 8 октября 2015 г., разрешающий «прекращение, приостановление работ по тушению в зонах контроля лесных пожаров при отсутствии угрозы населенным пунктам или объектам экономики в случаях, когда прогнозируемые затраты на тушение лесного пожара превышают прогнозируемый вред, который может быть им причинен» (курсив авт.).

Закономерно возникают два принципиальных и взаимосвязанных вопроса: насколько правомерен сам приказ № 426 и принятые на его основе решения КЧС с точки зрения (а) обеспечения безопасности людей и объектов экономики и (б) социально-экономической эффективности тушения пожаров.

Как свидетельствует многолетний отечественный и зарубежный опыт борьбы с лесными пожарами, главную угрозу жизни и здоровью людей (прежде всего - детей, престарельх, лии, страдающих респираторными заболеваниями и др.) представляет не огонь, а содержащий вредные и токсичные вещества дым от горящих деревьев и лесной подстилки. Этот смог накрывает населенные пункты, расположенные за сотни и тысячи километров от очага возгорания и пресловутых зон контроля. По данным мировой статистики лесных пожаров за последние 20 лет, обусловленная этим фактором преждевременная смертность на несколько порядков (!) превышает число погибших от огня: соответственно, 330 тыс. чел. против менее 30 в среднем в год [Burning out, 2018; Doerr, Santín, 2016].

Это же подтверждает и российская практика. Летом 2010 г. от воздействия дыма от лесных и торфяных пожаров, усугубившего вредоносность «фоновых» выбросов промышленности и транспорта в условиях аномальной жары, преждевременно ушли из жизни свыше 50 тыс. чел., что в сотни раз превысило число погибших от огня [Порфирьев, 2013].

\footnotetext{
2 Зоны контроля лесных пожаров устанавливаются органами исполнительной власти субъектов Российской Федерации, уполномоченных в области лесных отношений, в зоне осуществления лесоавиационных работ в лесах, расположенных на труднодоступных и удаленных территориях. URL: https://aviales.ru/default.aspx?textpage=229
} 
Это никоим образом не преуменьшает опасность огневого риска пожара - напротив, доказывает необходимость как можно более раннего начала действий по борьбе с огнем, независимо от того, на каком участке лесного массива возник пожар. Своевременность противопожарных действий позволяет не только снизить затраты на тушение огня (о них речь пойдет далее), но и значительно сократить площадь его распространения и, соответственно, масштабы возможного социального (здоровье и жизнь), экологического и экономического ущерба, риск которого особенно велик в случае сильного ветра и верхового огня. Лесные пожары лета 2019 г. стали лишним тому подтверждением. Так, в Красноярском крае они начинались с очагов всего в несколько десятков гектаров. При своевременных контрдействиях зона их реального контроля могла бы ограничиться этой площадью. Однако после того, как краевая КЧС приняла постановление об отказе от тушения удаленных очагов, огонь быстро охватил территорию в десятки тысяч гектаров, а дым от них - в сотни тысяч раз больше ${ }^{3}$.

В результате об «отсутствии угрозы населенным пунктам или объектам экономики» говорить уже не приходится. Хотя региональные органы здравоохранения пока официально не отчитались об увеличении числа респираторных и иных заболеваний, обусловленном загрязненным воздухом, заместитель главы МЧС России А.П. Чуприян был вынужден признать, что «качество жизни» в некоторых селах и городах ухудшилось ${ }^{4}$.

По сообщениям СМИ, в последних числах июля в Омске был отмечен 15\%-й рост обращений граждан к медикам; в с. Ванавара (Эвенкия) содержание канцерогенно-опасных взвешенных частиц в воздухе превысило предельно-допустимые концентрации, а в г. Улан-Удэ в первые дни августа Роспотребнадзор рекомендовал «минимизировать время пребывания на улице» и по возможности «выехать из зон задымления в места, где отсутствует смог от пожаров»5. Жители Киренска, а также ряда населенных пунктов Алтая в соцсетях жаловались на постоянную головную

\footnotetext{
${ }^{3}$ Власов Я. Почему не тушат лесные пожары в Сибири? [Эл. pecypc]. URL: https://tayga. info/147887 (дата обращения: 26.07.2019).

${ }^{4}$ В четырех регионах ввели режим ЧС из-за лесных пожаров [Эл. pecypc]. URL: https://ria.ru/20190730/1557006474.html (дата обращения: 26.07.2019).

${ }^{5}$ Воздух задымленного от пожаров Улан-Удэ признали опасным [Эл. pecypc]. URL: https://tayga.info/147983 (дата обращения: 01.08.2019).
} 
боль и общее недомогание, невозможность находиться на улице из-за дыма. Из-за него же в аэропортах Бодайбо, Киренска и Мамы на несколько дней в конце июля были отменены авиарейсы ${ }^{6}$, а в некоторых городах Алтайского края, Новосибирской и Кемеровской областей (подчеркнем, что в самих этих регионах леса не горели!) был введен режим «черного неба», устанавливающий ограничения или полный запрет выбросов промышленных предприятий․

Начиная с 29 июля 2019 г. в нескольких районах Бурятии, Республики Саха и по всей территории Красноярского края и Иркутской области (не только в ареалах лесных пожаров) был официально объявлен режим чрезвычайной ситуации. При этом без ответа осталась петиция с призывом ввести этот режим во всех затронутых огнем или дымом регионах Сибири, которая собрала в Сети около миллиона (!) подписей.

\section{Социально-экономическая эффективность борьбы с лесными пожарами}

Не выдерживает критики и используемый в приказе Минприроды РФ № 426 критерий непревышения прогнозируемых затрат на пожаротушение стоимости прогнозируемого вреда от пожара. Прежде всего, отметим, что в вопросах обеспечения безопасности личности, общества, государства неприемлем «бухгалтерский» подход к оченке эффективности затрат, которым, судя по опубликованной информации, руководствовались КЧС.

Во-первых, вызывают много вопросов результаты оценки прогнозных затрат. Например, 4 июля 2019 г. КЧС Красноярского края приняла решение отказаться от тушения 33 пожаров в Северо-Енисейском районе и Эвенкии общей площадью 891 га, исходя из оценки ожидаемого ущерба от гибели леса в 4,87 млн руб. (примерно 5,5 тыс. руб./га) и затрат на борьбу с огнем в 139,1 млн руб. ${ }^{8}$ Таким образом, в расчете на 1 га затраты были оценены примерно в 156 тыс. руб.

\footnotetext{
${ }^{6}$ «Жалко до слез!» К чему приведут крупнейшие лесные пожары в Сибири [Эл. pecypc]. URL: https:/ria.ru/20190730/1556981900.html (дата обращения: 01.08.2019).

${ }^{7}$ При этом в Красноярске, который гораздо ближе к горящему лесу, такой режим тогда установлен не был, несмотря на протесты жителей и даже рекомендации губернатора. См.: Власов Я. Почему не тушат лесные пожары в Сибири? [Эл. pecypc]. URL: https:/tayga. info/147887 (дата обращения: 26.07.2019).

${ }^{8}$ Власов Я. Почему не тушат лесные пожары в Сибири? [Эл. pecypc]. URL: https://tayga. info/147887 (дата обращения: 26.07.2019).
} 
Между тем, по данным полпреда Президента России в Сибирском федеральном округе С.И. Меняйло, в 2016 г. фактические затраты на тушение 1 млн га лесов составили 1,5 млрд руб. (или 1,5 тыс. руб./га) ${ }^{9}$. По данным заместителя руководителя Рослесхоза Н. Кротова на ноябрь 2018 г., при общей площади тушения лесных пожаров в 2017 г. 1,3 млн га, в 2018 г. - 1,7 млн га, российский бюджет затратил на эти цели 3 млрд руб. ${ }^{10}$ Это составляет примерно 1/5 всех расходов на лесоохрану, которые в последние годы находятся на уровне 14-18 млрд руб. (рис. 2).

Таким образом, уровень затрат на 1 га лежит в интервале, округленно, от 1,8 тыс. до 2,3 тыс. руб., или в среднем 2 тыс. руб./га. Наконец, напомним, что, согласно распоряжению Правительства РФ от 08.08.2019 № 1770- ${ }^{11}$, из резервного фонда было выделено 5,99 млрд руб. (а) Рослесхозу - на предоставление субвенций трём сибирским субъектам РФ; (б) МЧС и Минобороны - на покрытие расходов по тушению лесных пожаров в зонах контроля этих трёх регионов площадью 2,91 млн га, что в среднем округленно дает те же 2 тыс. руб./га.

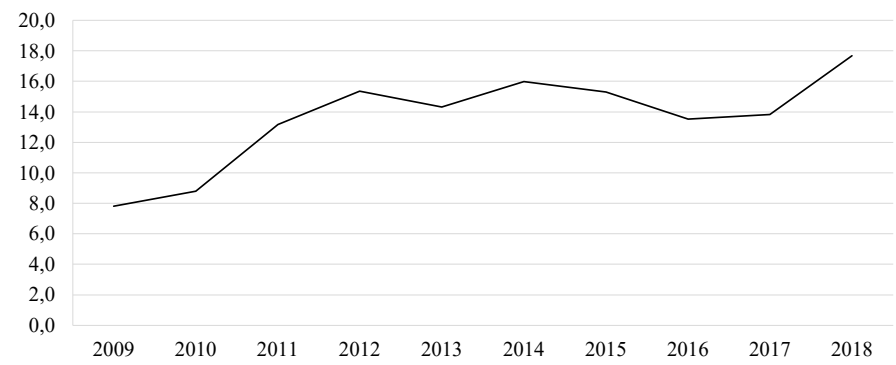

Источник: данные Росстата.

Рuc. 2. Расходы на охрану лесов от пожаров в России в 2009-2018 гг., млрд руб.

\footnotetext{
${ }^{9}$ Стали известны расходы на тушение лесных пожаров в Сибири в 2016 г. [Эл. ресурс]. URL: https://ria.ru/20161209/1483184201.html (дата обращения: 28.07.2019).

${ }^{10}$ B Рослесхозе сравнили затраты России и США на тушение лесных пожаров [Эл. pecypc]. URL: https://ria.ru/20181128/1533685100.html (дата обращения: 28.07.2019).

${ }^{11}$ Распоряжение Правительства РФ от 08.08.2019 № 1770-р «О выделении в 2019 году Рослесхозу из резервного фонда Правительства Российской Федерации бюджетных ассигнований на предоставление субвенций из федерального бюджета на финансовое обеспечение мероприятий по тушению лесных пожаров на территории Республики Саха (Якутия), Красноярского края, Иркутской области» [Эл. ресурс]. URL: https://rulaws. ru/goverment/Rasporyazhenie-Pravitelstva-RF-ot-08.08.2019-N-1770-r/ (дата обращения: 18.08.2019).
} 
Во-вторых, весьма спорна оценка результативности затрат только в виде снижения прямого материального ущерба (гибели леса). Не говоря уже о том, что ущерб от сгоревшего леса не ограничивается утратой древесины (больший урон наносит разрушение лесных экосистем и связанное с этим значительное снижение ценности экосистемных услуг), основные угрозы для здоровья и благополучия населения и потери для экономики сопряжены с последствиями задымления и загрязнения воздуха, которые по какой-то причине во внимание не принимаются. Это ведет к значительной недооценке прогнозируемого вреда от лесных пожаров, тем самым оправдывая непринятие мер по их тушению.

О масштабах недооценки можно судить по опыту 2010 г. Согласно официальным данным Росстата, прямой материальный ущерб от лесных пожаров за этот год (стоимость утраченной древесины и сгоревших примерно 1200 домов) достиг 85,5 млрд руб. (рис. 3). В то же время, по нашей оценке [Порфирьев, 2013. С. 57, 59], стоимость социально-экономических потерь от преждевременной смертности только в г. Москве составила 123 млрд руб., а для всей страны - более 550 млрд руб., что, соответственно, почти в полтора и шесть раз превысило материальный ущерб.

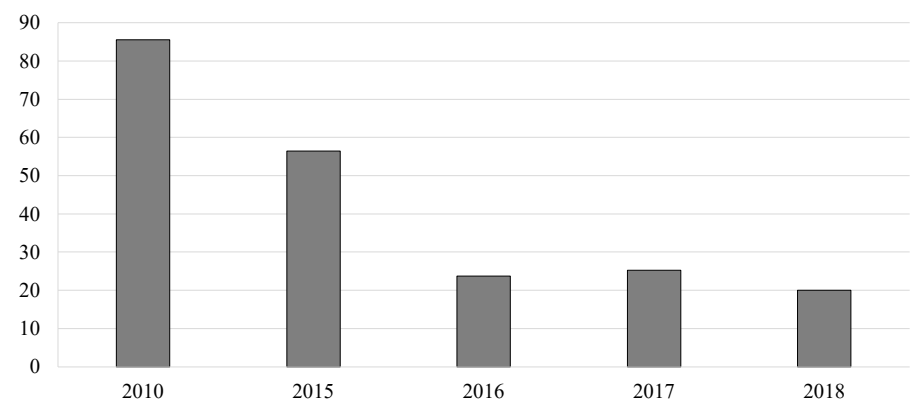

Источник: данные Росстата, Счетной палаты РФ и СМИ (Regnum.ru, Lenta.ru).

Puc. 3. Материальный ущерб от лесных пожаров в России в 2010-2018 гг., млрд руб.

На наш взгляд, главной целью и ключевым критерием результативности усилий и затрат на тушение лесных пожаров должно быть максимальное снижение рисков для жизни 
и здоровья людей, а его социально-экономическая интерпретация в виде соотнесения ценности спасенных жизней и здоровья с указанными затратами - критерием их экономической эффективности.

Согласно принятому ВО3 критерию, экономически эффективными считаются затраты на спасение (продление) одного года жизни среднестатистического индивида, не превышающие утроенной величины ВВП на душу населения данной страны. Если же затраты находятся в пределах среднедушевого ВВП, международное сообщество признает их «высокоэффективными» [WHO.., 2001]. Исходя из этих критериальных показателей при наличии необходимых данных по численности и составу населения в зоне задымления, можно рассчитать эффективность затрат - они же экономические выгоды снижения риска здоровью и жизни людей - от мер пожаротушения.

Поскольку официальные данные о площади и интенсивности задымления отсутствуют, сделаем грубую оценку, чтобы получить представление о порядке величины эффективных затрат на тушение лесных пожаров в Сибири.

Вначале напомним, что в июне - начале июля 2019 г. площадь лесных пожаров в макрорегионе оценивалась всего лишь несколькими десятками гектаров. Предположим, что суммарная площадь горения не превышала 200 га. Тогда, с учетом фактических затрат на тушение таких пожаров в Сибири в 2016 г,, их величина летом 2019 г. (с поправкой на инфляцию) должна была бы составить примерно 1,6 тыс. руб./га. То есть, будь меры по тушению приняты своевременно, общая сумма в текущих ценах не превысила бы 350 тыс. руб.

Далее, исходя из реальной ситуации на конец июля 2019 г., прикинем стоимость тушения лесных пожаров в зонах контроля. Как уже отмечалось, общая площадь, охваченная огнем, достигала 3,3 млн га, и лишь на 3,3\% этой площади пожары были ликвидированы. Если мы экстраполируем фактические затраты на тушение (1,6 тыс. руб./га) на все зоны контроля (а это примерно 3,2 млн га), получится, что стоимость тушения лесных пожаров в них должна составить около 5 млрд руб. Полученная оценка корреспондирует с суммой 5,99 млрд руб., 
выделенной из резервного фонда для тушения пожаров в указанных зонах ${ }^{12}$.

Наконец, определим величину эффективных затрат на тушение лесных пожаров в Сибири по критериям ВОЗ. Основываясь на информации в СМИ, общую численность населения, оказавшегося в зоне опасного задымления, можно оценить примерно в 5,0-5,5 млн чел ${ }^{13}$.

Насколько велик для них риск утраты здоровья? Согласно данным Роспотребнадзора, озвученным на совещании Правительства РФ в Красноярске 31.07.2019, в регионе регистрировались единичные превышения содержания в воздухе $\mathrm{CO}_{2}$, взвешенных веществ и мелкодисперсных фракций пыли с уровнем 1-4 ПДК, но не более 5 ПДК; рост обращаемости населения в скорую помощь в пиковые дни загрязнения (до 5 ПДК) - не превышал $10 \%$, исходя из чего руководители ведомства сделали вывод о том, что «высоких рисков для здоровья на сегодняшний день нет ${ }^{14}$. Однако стоит иметь в виду, что все перечисленные вещества - канцерогены, в отношении которых даже показатель ПДК, устанавливаемый для всего населения, не означает безопасного уровня для групп риска (пожилые, дети, страдающие респираторными заболеваниями). Не случайно в материалах Роспотребнадзора указанные группы выделены в особую категорию. И как в связи с этим воспринимать упомянутую в том же докладе информацию о «подворных обходах в тех районах, где есть высокие риски» (курсив авт.) $)^{15}$ ?

Даже если принять консервативное допущение о том, что в зоне опасного задымления уровень риска преждевременной

\footnotetext{
12 До распоряжения Правительства Российской Федерации от 08.08.2019 № 1770-p, выступая на специальном совещании правительства России 31.07.2019 в Красноярске глава Минприроды РФ заявлял о более скромных намерениях правительства - от 2,5 млрд до 3 млрд руб. (См.: О ситуации с лесными пожарами на территории Сибирского федерального округа. 31 июля 2019 г. 19:00. Совещание [Эл. pecypc]. URL: http://m. government.ru/news/37523/\#kobilkin (дата обращения: 05.08.2019). При этом в обоих случаях речь, по сути, идет о дополнительных расходах, требуемых для тушения пожаров в зонах контроля, главным образом силами авиации МЧС и Минобороны России.

${ }^{13}$ По другим оценкам, ПДК продуктов горения были превышены на территориях с населением более 10 млн чел. См: Иноземцев В. Экономика экстерналий: почему низкий рост ВВП дорого обходится России. [Эл. ресурc]. URL: www.rbc.ru/opinions/ec onomics/30/08/2019/5d6784f69a7947ade6226ff8 (дата обращения: 07.09.2019).

${ }^{14} \mathrm{O}$ ситуации с лесными пожарами на территории Сибирского федерального округа [Эл. pecypc]. URL: http://m.government.ru/news/37523/\#popova (дата обращения: 05.08.2019).

15 Там же.
} 
смерти не превышает нормативно установленной величины $1,8 \times 10^{-5}$ в год для региона Сибири ${ }^{16}$, риск для всего населения в указанной зоне может быть оценен на уровне около 100 человек, или 3000 человеко-лет, согласно методике ВОЗ. Для сравнения: эти потери в 550 раз меньше, чем при пожарах 2010 г., хотя количество людей в зоне риска в 2019 г. было меньше примерно в 7-8 раз.

Исходя из рекомендованных ВО3 критериев эффективности затрат на спасение, их величина для России составляет примерно 2,1 млн руб./чел.-год (эффективные) и 700 тыс. руб./чел.-год (высокоэффективные затраты) ${ }^{17}$. Применительно к лесным пожарам Сибири получаем, что стоимость эффективных и высокоэффективных затрат составляет 6,3 млрд руб. и 2,1 млрд руб., соответственно.

Сопоставление приведенных оценок показывает, что, во-первых, расчетные суммы затрат на тушение лесных пожаров в так называемых зонах контроля могут считаться эффективными с социально-экономической точки зрения (не говоря уже о гуманитарной, общечеловеческой позиции). Даже максимальная величина затрат (139,1 млн руб., в которые оценили противопожарные меры КЧС Красноярского края) укладывается в сумму эффективных расходов на цели защиты жизни и здоровья местного населения, определенную по методике ВОЗ. Во-вторых, затраты по ограничению (локализации) очагов лесных пожаров на ранних этапах, в том числе на доступных для сил и средств пожаротушения участках зон контроля, являются, согласно методике ВО3, высокоэффективными. Прежде всего, потому, что эти меры могли бы значительно сократить площадь горения, а значит - и территорию задымления и, соответственно, риск для жизни и здоровья людей. Даже если принять за точку отсчета завышенную оценку красноярской КЧС (156 тыс. руб./га), общие расходы на меры ранней локализации лесных пожаров в июне начале июля 2019 г. составили бы около 30 млн руб., что почти на два порядка меньше уровня высокоэффективных затрат, определенного по методике ВОЗ.

\footnotetext{
${ }^{16}$ ГОСТ Р 22.10.02-2016 Безопасность в чрезвычайных ситуациях. Менеджмент риска чрезвычайной ситуации. Допустимый риск чрезвычайных ситуаций. (Дата введения 2017-06-01). [Эл. ресурс]. URL: http://docs.cntd.ru/document/1200136698 (дата обращения: 05.08.2019).

${ }^{17}$ Оценки на основе данных о стоимости ВВП/душу населения России в конце 2018 г.
} 
Своевременные затраты и усилия обеспечили бы не только сокращение прямого ущерба лесам, их флоре и фауне, но и в целом сохранение ценности всех экосистемных услуг лесов, включая их потенциал поглощения парниковых газов и депонирования углерода. По расчетам ученых Красноярского научного центра СО РАН и их германских коллег, при сгорании 1 кг сухого вещества лесной подстилки во время лесных пожаров в Сибири в воздух попадает 4 г метана $\left(\mathrm{CH}_{4}\right)$, более 100 г угарного (CO) и 1,5 кг углекислого $\left(\mathrm{CO}_{2}\right)$ газа. Во время интенсивного горения древесины концентрация указанных парниковых газов по сравнению с фоновым содержанием в воздухе увеличивается, соответственно: $\mathrm{CH}_{4}$ - вдвое, $\mathrm{CO}$ - почти в 30 раз и $\mathrm{CO}_{2}-$ на $8 \%{ }^{18}$. При этом только по предварительным оценкам на конец июля 2019 г., объем вредных выбросов в результате лесных пожаров составил 50 млн т в $\mathrm{CO}_{2}$-эквиваленте ${ }^{19}$, а потенциал поглощения $\mathrm{CO}_{2}$ лесами сократился на 12 млн $\mathrm{T}^{20}$.

С учетом этих факторов совокупная (не только социальноэкономическая, но и экологическая, и «климатическая») эффективность затрат по ранней локализации тушения лесных пожаров должна быть оценена еще выше.

Возвращаясь к вопросу об обоснованности приказа Минприроды № 426 от 2015 г. и принятых исходя из него решений КЧС, отметим, что предписанное документом сравнение прогнозируемых затрат на тушение пожара и прогнозируемого вреда от него должно выполняться сверхоперативно. Как в очередной раз показали лесные пожары 2019 г., промедление значительно увеличивает масштабы бедствия со всеми вытекающими отсюда последствиями. В то же время прогнозные расчеты и оценки затрат и вреда - процесс трудоемкий, требующий соответствующей информации и квалификации для модельных расчетов сценариев развития пожара и оценки вероятных рисков, причем не только

\footnotetext{
${ }^{18}$ Выброс парниковых газов из-за лесных пожаров в Сибири увеличился в несколько раз. [Эл. ресурc]. URL: http://www/interfax.ru/russia/621543 (дата обращения: 27.07.2019).

19 Ученый предупредил о рекордных выбросах $\mathrm{CO}_{2}$ из-за лесных пожаров. [Эл. ресурс]. URL: https://ria.ru/20190723/1556799588.html (дата обращения: 27.07.2019). Есть основания считать, что этот показатель существенно выше, учитывая, что, по оценкам Европейского центра среднесрочного прогноза погоды, выбросы от пожаров на территориях внутри Полярного круга превысили 100 млн т. См: [Ice and fire, 2019].

${ }^{20}$ Оценка сделана, исходя из среднегодовой величины объема поглощения углекислого газа лесами в 3,9 т/га на основе данных по бореальным лесам региона ХМАО-Югра. См: [Крупинин, 2009. С. 31].
} 
огневых, но и экологических (задымление), с особенным вниманием к состоянию здоровья людей, входящих в группу риска. Как показал печальный опыт 2010 г., последние особенно уязвимы к воздействию задымленного и загрязненного воздуха.

Насколько известно, такими инструментарием и данными ни КЧС, ни Минприроды РФ не располагают. Кризисная ситуация в области оценки и управления рисками лесных пожаров, а также в сфере борьбы с этими пожарами в России, сложившаяся после принятия нового Лесного кодекса и реформирования «Авиалесоохраны», по сути, не изменилась. Конкретные разработки ученых РАН, направленные на ее улучшение (см., например, [Кудрявцев и др., 2008]), годами остаются без движения ${ }^{21}$. Возможно, драматические события лета 2019 г. в Сибири заставят власти по-иному взглянуть на них. Например, в двух лесничествах в Красноярском крае начали применять компьютерную систему прогноза возникновения и развития лесных пожаров, недавно разработанную специалистами Института леса имени В.Н. Сукачева $\mathrm{PAH}^{22}$. Тем не менее пока нельзя говорить ни об оперативности, ни о высоком качестве оценок и прогнозов региональных КЧС.

По горячим (в прямом и переносном смысле) следам масштабных лесных пожаров 2019 г. исполнительная и законодательная власти заговорили о необходимости изменения действующего регламента пожаротушения. На специальном совещании в Правительстве РФ 31 июля 2019 г. Д. Медведев заявил о целесообразности пересмотра принципов установления зон контроля, «поскольку они сейчас охватывают только места, где непосредственно пожар, где уже пламя бушует, но не распространяются, например, на зоны задымления» ${ }^{23}$. На пересмотре настаивают и МЧС России, самолеты которого используются для тушения

${ }^{21}$ Справедливости ради отметим, что даже в ведущей экономике мира, США, дело обстоит не лучшим образом: «Ни одно правительство штата или агентство не предприняли серьезных усилий для моделирования ситуации с тем, чтобы выявить потребности в ресурсах пожаротушения, определить приоритетные зоны защиты от пожаров и масштабы необходимых для этого затрат»,- пишут эксперты [Alaska Hotspots, 2019].

22 Российские ученые разработали систему, прогнозирующую вероятность появления лесных пожаров [Эл. pecypc]. URL: https://tass.ru/nauka/6733111 (дата обращения: 05.08.2019).

${ }^{23}$ О ситуации с лесными пожарами на территории Сибирского федерального округа. Совещание [Эл. ресурс]. URL: http:/government.ru/news/37523/ (дата обращения: 31.07.2019). 
пожаров ${ }^{24}$, и депутаты Государственной думы, которые подчеркивают, что при оценке ущерба «нужно учитывать вред, наносимый людям». Более того, в последних числах июля в Госдуму был внесен законопроект, запрещающий отказываться от тушения лесных пожаров на основании прогноза о возможном ущербе. Фактически речь идет об отмене пресловутого приказа № $426^{25}$.

В контексте этих инициатив и сохранявшейся тяжелой ситуации с лесными пожарами в Сибири, руководство Минприроды поручило Рослесхозу совместно с регионами «пересмотреть границы зон контроля лесных пожаров таким образом, чтобы не только исключить вероятность перехода лесных пожаров на населенные пункты и объекты экономики, но и предотвратить задымление населенных пунктов, в том числе на территориях прилегающих субъектов РФ» ${ }^{26}$. При этом ведомство принимает во внимание, что указанные действия могут потребовать привлечения дополнительных сил и средств. Так, в Сибири для тушения лесных пожаров в дополнение к авиации МЧС по распоряжению Президента России с 1 августа были привлечены Ил-76 Министерства обороны страны, что фактически означает необъявленное повышение статуса этого бедствия до федерального уровня.

\section{Заключительные замечания}

Весь ход развития событий вокруг ситуации, сложившейся в Сибири летом 2019 г., лишний раз показал, что борьба с лесными пожарами по своей значимости относится к категории задач обеспечения национальной безопасности ${ }^{27}$. Решение такой задачи требует, во-первых, отказа от существующего подхода, при котором защита здоровья и жизни миллионов людей, не говоря

\footnotetext{
${ }^{24}$ К тушению лесных пожаров на севере Красноярского края самолеты МЧС Бе-200 были привлечены лишь 31 июля 2019 г.

${ }^{25}$ В Госдуму внесли законопроект, запрещающий не тушить лесные пожары [Эл. pecypc]. URL: https://tass.ru/obschestvo/6719863 (дата обращения: 31.07.2019).

${ }^{26}$ Глава Минприроды России поручил Рослесхозу совместно с регионами пересмотреть границы зон контроля труднодоступных лесных пожаров [Эл. ресурc]. URL: http://www. mnr.gov.ru/press/news/glava_minprirody_rossii_poruchil_rosleskhozu_sovmestno_s regionami_peresmotret_granitsy_zon_kontrolya/ (дата обращения: 30.07.2019).

27 Это подтверждает и оперативное совещание с постоянными членами Совета Безопасности, которое Президент России провел 5 августа 2019 г. и одной из главных тем которого стала ситуация с ликвидацией лесных пожаров в Сибири. См. Совещание с постоянными членами Совета Безопасности [Эл. ресурс]. URL: http://kremlin.ru/events/ president/news/61272 (дата обращения: 05.08.2019).
} 
уже о миллионах гектаров тайги, по сути, зависит от качества приказа одного министерства и качества принятия решений региональной КЧС и финансовых и материально-технических ресурсов конкретного региона.

Более, того, приказ Минприроды № 426, на котором основан этот подход, противоречит федеральным законам «О пожарной безопасности» от 21.12.1994 № 69-Ф3 (с изменениями на 26.07.2019) и «Техническому регламенту о требованиях пожарной безопасности» от 22.07.2008 № 123-Ф3 (ред. от 27.12.2018), определяющим зону пожара как территорию, «на которой существует угроза причинения вреда жизни и здоровью граждан, имуществу физических и юридических лиц в результате воздействия onacнblх факторов пожара» (см. ст. 1 ФЗ-69 и ст. 9 Ф3-123). Последние, помимо пламени и искр, к которым апеллирует приказ № 426, включают «тепловой поток, повышенную температуру окружающей среды, повыщенную концентрацию токсичных продуктов горения и термического разложения, пониженную концентрацию кислорода, снижение видимости в дымму» (курсив авт.).

Масштаб и серьезность проблемы требуют поднятия ее решения на федеральный уровень, с опорой на системнылй, комплексный подход. Это предполагает принятие принципиальных институциональных изменений, прежде всего, в Лесном кодексе и в организации лесной службы страны; радикальное улучшение координации действий ведомств и региональных властей, позволяющее 1) повысить качество мониторинга и оценки обстановки, 2) обеспечить своевременное введение режима ЧС и при необходимости - повышение его статуса с регионального до федерального уровня, с целью усиления группировки сил и средств для ликвидации пожаров. Перечисленные усилия должны быть обеспечены соответствующими материально-техническими и финансовыми ресурсами. Пока этого не удается добиться, в том числе из-за недооценки значимости затрат на борьбу с лесными пожарами.

В связи с этим, во-вторых, нужен не менее решительный отказ от фискального подхода к оченке эффективности затрат на противопожарные меры, от которых, по сути, зависят здоровье и качество жизни людей. Такой подход к обеспечению безопасности населения неприемлем в любой цивилизованной 
стране, тем более - в России, которая Конституцией определена как социальное государство, где человек является высшей ценностью. Главным критерием эффективности затрат на защиту от воздействия опасных факторов лесных пожаров (в том числе - задымления) должно быть сохранение жизни и здоровья людей, а сохранность леса (не только древесины!) - вторым по значимости критерием и результатом этих затрат.

Безусловно, в условиях ограниченности финансовых и материально-технических ресурсов нельзя оставить в стороне вопрос об экономической эффективности расходов. Однако, на наш взгляд, он должен рассматриваться исключительно в контексте наилучшего использования ограниченных ресурсов для обеспечения безопасной жизнедеятельности максимального возможного числа людей. Именно такой подход отражают упомянутые в статье критерии ВОЗ. Как доказывают наши расчеты, выполненные на основе этих критериев, в случае принятия своевременных решений и мер, затраты оказываются высокоэффективными.

К тому же нельзя признать допустимым отказ от тушения пожара на удаленных от населенных пунктов зонах контроля только лишь из-за нецелесообразности расходования средств в отсутствие явной угрозы огня для людей и хозяйственных объектов. Последнее, как было показано выше, не соответствует действительности: по мере распространения огня эти угрозы возрастают, а возможности локализации пожара сокращаются. При этом, согласно имеющейся статистике, именно на зоны контроля приходится максимальная площадь лесов, пройденных огнем. По спутниковым данным системы ИСДМ-Рослесхоз, общая площадь, пройденная лесными пожарами в этих зонах, в 2017 г. составила 3,2 млн га, или 58\% всей пройденной лесными пожарами территории страны; в 2018 г. эти показатели увеличились до 5,9 млн га и $59 \%$, соответственно (в обоих случаях - за весь пожароопасный сезон). В 2019 г. за период с начала пожароопасного сезона по 12 августа общая площадь, пройденная лесными пожарами в зонах контроля, достигла 7,6 млн га ${ }^{28}$.

Что касается реально труднодоступных удаленных лесных массивов, вероятно, за ними нужно сохранить статус зон

\footnotetext{
${ }^{28}$ Рассчитано по данным: Greenpeace подготовил предложения по пересмотру «зон контроля» [Эл. ресурс]. URL: https://greenpeace.ru/news/2019/08/15/greenpeace-podgotovilpredlozhenija-po-peresmotru-zon-kontrolja/ (дата обращения: 06.09.2019).
} 
контроля тушения пожаров, но для начала необходимо поставить вопрос о сокращении числа и площади (границ) таких зон ${ }^{29}$. В связи с этим, на наш взгляд, заслуживают серьезного внимания предложения Российского отделения НПО Greenpeace, рекомендующего исключить из этих зон эксплуатационные леса (в которых планируется промышленная заготовка древесины в течение ближайших 20 лет и которые, таким образом, не являются «труднодоступными»); леса, расположенные менее чем на 10 км от населённых пунктов, железных дорог, автодорог федерального и регионального значения, а также особо охраняемых природных территорий, в отношении которых высок риск опасного задымления или перехода огня в течение нескольких часов; а также леса в границах Северо-Западного ФО, пожары в которых, с одной стороны, могут привести к опасному задымлению густонаселённых районов Европейско-Уральской России; с другой, почти всегда доступны для тушения. Перечисленные лесные территории в совокупности занимают более половины (52\%) суммарной площади существующих зон контроля тушения пожаров ${ }^{30}$.

Далее, нужно обеспечить лучшую локализацию очагов возгораний. Этого можно добиться лишь за счет радикальной модернизации инструментария мониторинга и оценки рисков, что требует, прежде всего, качественного повышения роли науки и современных технологий. В том числе, использования возможностей национального проекта «Наука» (меры которого пока ориентированы главным образом на улучшение публикационной активности).

Следующий шаг - радикальное усовершенствование системы тушения пожаров, включая авиацию. В частности, новое руководство Рослесхоза предлагает после сокращения зон контроля создать новые отделения «Авиалесоохраны» вблизи или внутри оставшихся зон [Если пожар..., 2019]. Один из центров противодействия лесным пожарам, оснащенный средствами наблюдения

\footnotetext{
${ }^{29}$ Во всей стране, по данным Рослесхоза, контрольные зоны имеются в 23 субъектах Российской Федерации.

${ }^{30}$ Greenpeace подготовил предложения по пересмотру «зон контроля» [Эл. ресурс]. URL: https:/greenpeace.ru/news/2019/08/15/greenpeace-podgotovil-predlozhenija-poperesmotru-zon-kontrolja/ (дата обращения: 06.09.2019).
} 
и тушения, включая авиатехнику, будет расположен в Богучанском районе Красноярского края ${ }^{31}$.

Наконец, необходимо решить ключевые вопросы качественного улучшения финансирования, укомплектованности личным составом и оснащенности не только пожарной, но и всей лесной службы страны. Если исходить из приведенных оценок расходов на тушение пожаров в зонах контроля (2 тыс. руб./га) и доли указанных зон в общей площади лесов, пройденной огнем (около $60 \%$ в 2017 и 2018 гг.), получим, что на защиту лесов от пожаров необходимо ежегодно выделять не менее 25 млрд руб. ${ }^{32}$ Это более чем в 1,5 раза выше затрат на всю лесоохрану в последние годы.

Решение перечисленных вопросов выходит за рамки полномочий региональных властей и Минприроды России и требует вмешательства на уровне высшей исполнительной и законодательной власти страны. В то же время на ведомственном уровне остается актуальной необходимость радикального пересмотра приказа Минприроды России № 426, поскольку для региональных КЧС он все еще является руководством к действию. Так, несмотря на то, что Минприроды в августе 2019 г. не просто заявило о намерении, но уже поручило Рослесхозу начать пересмотр границ зон контроля, по данным «Авиалесоохраны» на 09.09.2019, работы по тушению 88 лесных пожаров были прекращены решением региональных КЧС на основании того же приказа и с той же аргументацией ${ }^{33}$.

Нужно в полной мере воспользоваться опытом и уроками масштабных лесных пожаров нынешнего лета и предшествующих годов для радикального улучшения ситуации в сфере предупреждения и ликвидации чрезвычайных ситуаций. Слишком высока цена - жизнь и здоровье людей, а значит - «безопасность личности, общества и государства».

${ }^{31}$ С.И. Меняйло рассказал об авиационной базе для тушения пожаров в Сибири. [Эл. pecypc]. URL: https://krsk.rbc.ru/krsk/30/08/2019/5d68aefd9a7947ed7a9ce2d (дата обращения: 06.09.2019).

32 По оценкам специалистов Российского отделения НПО Greenpeace, чтобы в целом обеспечить минимально приемлемый уровень охраны лесов на землях лесного фонда от огня и тушения лесных пожаров, нужно довести финансирование до 26-30 млрд руб. в год». См.: Greenpeace подготовил предложения по пересмотру «зон контроля» [Эл. pecypc]. URL: https:/greenpeace.ru/news/2019/08/15/greenpeace-podgotovil-predlozhenijapo-peresmotru-zon-kontrolja/ (дата обращения: 06.09.2019).

${ }^{33}$ О лесопожарной обстановке в России на 00:00 мск 08.09.2019 [Эл. ресурc]. URL: https://aviales.popup.aspx?news=5591 (дата обращения: 10.09.2019). 


\section{Литература}

«Если пожар недоступен, то, как бы он ни назывался, мы все равно туда не попадем». Врио главы Рослесхоза Михаил Клинов о лесных пожарах в Сибири и на Дальнем Востоке // Коммерсанть. 2019. 9 авг.

Крупинин Н.Я. Методология мониторинга развития лесного хозяйства и лесопользования на интенсивно осваиваемых территориях (на примере ХМАО-Югры). Автореф. канд. дисс. М., 2009.

Кудрявиеев М.Ю., Лукин В.В., Малинеикий Г.Г., Митин Н.А., Науменко С.А., Подлазов А.В., Румянцев А.А., Торопьгина С.А. Управление рисками лесных пожаров на территории Российской Федерации. Препринт. М: Институт прикладной математики им. М.В. Келдыша РАН, 2008.

Непомнящая Д. В пожарах в России сгорело более 2,5 млн га леса // Российская газета. 2019. 9 авг.

Порфирьев Б. Пожар по приказу // Эксперт. 2019. № 34 (19-25 августа). C. $48-51$.

Порфирьев Б. Экономическая оценка людских потерь в результате чрезвычайных ситуаций // Вопросы экономики. 2013. № 1. С. 46-68. Doi: 10.32609/0042-8736-2013-1-48-68.

Alaska Hotspots. The Economist. 2019. July 27 $7^{\text {th }}$ P. 35.

Burning out. The Economist. 2018. November $17^{\text {th }}$. P. 81.

Doerr, S.H., Santín, C. Global trends in wildfire and its impacts: perceptions versus realities in a changing world. Philosophical Transactions of the Royal Society of Britain. 2016. Vol. 371. No. 1696. Article ID20150345. Doi: 10.1098/ RSTB.2016.0149.

Ice and fire. The Economist. 2019. August $3^{\text {rd }}$. P. 22.

WHO Commission on Macroeconomics and Health. Macroeconomics and Health: Investing in Health for Economic Development. Geneva: World Health Organization. 2001.

Статья поступила 13.09.2019.

Для цитирования: Порфирьев Б. Н. О мнимой и реальной экономической эффективности борьбы с лесными пожарами// ЭКО. 2019. № 11. С. 8-26. DOI: 10.30680/ECO0131-7652-2019-11-8-26.

\section{Summary}

Porfiriev, B.N., Member of RAS, Institute for Economic Forecasting, RAS, Moscow

Alleged and Actual Economic Effectiveness of Fighting Wildfires in Siberia

Abstract. The paper contains a critical evaluation of economic substantiation of decisions by responsible governmental and regional bodies on fighting large-scale wildfires in the summer of 2019 in Siberia. The author believes that the abovementioned substantiation considerably underestimates the risk to human life and health posed by fires. Based on (a) priorities of hazards to safety of communities, primarily those most vulnerable to the impact (the deadliest threat stems from smoke containing toxic and hazardous substances rather than blaze); and (b) WHO criteria of economic efficiency of rescue measures, it is argued that the costs (expenses) of 
extinguishing wildfires are socioeconomically effective. Moreover, the costs of timely measures on localization of wildfires in areas without settlements and installations (the so-called control zones) that have hotspots accessible to ground or air firefighting operations are considered highly effective. The paper argues that wildfire safety should be regarded as a national security issue requiring comprehensive policy which repudiates a formal fiscal approach still used to evaluate effectiveness of measures to reduce hazards to human health and save human lives.

Keywords: wildfires; control zones; fire extinguishing measures; costs; human life and health; socioeconomic effectiveness; natural hazards; Arctic; public governance

\section{References}

"If a fire is out of reach, we will not get there anyway, no matter how we call it”. temporarily acting Rosleshoz' director Mikhail Klinov on forest fires in Siberia and on the Far East. (2019). Kommersant”. August $9^{\text {th }}$. (In Russ.).

Krupinin, N. Ya. (2009). Methodology of monitoring forestry development on territories of intensive economic activity (using Khanty-Mansiysk autonomous okrugUgra as benchmark. Avtoref. kand. diss. Moscow. (In Russ.).

Kudryavtsev, M. Yu., Lukin, V. V., Malinetskii, G. G., Mitin, N.A., Naumenko, S.A., Podlazov, A.V., Rumyantsev, A.A., Toropygina, S.A. (2008). Managing risks of forest fires on territory of the Russian Federation. Working paper. Moscow. Institut prikladnoi matematiki iM. M. V. Keldysha RAN (Publ.)

Nepomnyashchaya, D. (2019). In Russian fires 2,5 million hectares of forests has burned. Rossiiskaya gazeta. August $9^{\text {th }}$.

Porfiriev, B. (2019). Fire on order. Expert. No. 34. Pp. 48-51.

Porfiriev, B. (2013). Economic Evaluation of Human Losses from Disasters. Voprosy Ekonomiki. No. 1. Pp. 46-68. Doi: 10.32609/0042-8736-2013-1-48-68 (In Russ.).

Alaska Hotspots (2019). The Economist. July 27th. P. 35.

Burning out (2018). The Economist. November $17^{\text {th }}$. P. 81.

Doerr, S.H., Santín, C. (2016). Global trends in wildfire and its impacts: perceptions versus realities in a changing world. Philosophical Transactions of the Royal Society of Britain. Vol. 371. No. 1696. Article ID20150345. Doi: 10.1098/ RSTB.2016.0149.

Ice and fire (2019). The Economist. August $3^{\text {rd }}$. P. 22.

WHO Commission on Macroeconomics and Health. (2001). Macroeconomics and Health: Investing in Health for Economic Development. Geneva: World Health Organization.

For citation: Porfiriev, B.N. (2019). Alleged and Actual Economic Effectiveness of Fighting Wildfires in Siberia. ECO. No. 11. Pp. 8-26. (In Russ.). DOI: 10.30680/ ECO0131-7652-2019-11-8-26. 